\title{
Influence of activation of microsphere and latex base addition on mechanical properties of concrete
}

\author{
Wioletta Dobaczewska ${ }^{1}$, Wojciech Kubissa ${ }^{2}$, Karol Prałat ${ }^{3}$, Patryk Tomczak ${ }^{4}$ \\ Warsaw University of Technology, Faculty of Civil Engineering, Mechanics and Petrochemistry, \\ Łukasiwicza 17, 09-402 Plock, Poland \\ E-mail: ' wiola.godlewska@interia.eu (corresponding author)
}

\begin{abstract}
In a modern civil engineering, it is important to erection construction in extremely complicated and difficult environmental conditions. Additives and admixes to concrete enable to achieved higher mechanical properties of concrete mixtures. This operation causes, the constructions accomplish durability in various environmental conditions. In the article, authors described scientific research made on concrete with additives: latex based polymer and microspheres. The tested additives were used in to different proportion each and they were combined with each other. The aim of research was to determine influence this two additives on compressive strength after 28 days, after 90 days, a tensile splitting strength, a sorptivity, a freeze-thaw resistance and a compressive strength on the specimens after freeze-thaw resistance test. Received results clearly show decrease in compressive strength of the modified concrete mixtures. The specimens prepared without additives achieved the highest compressive strength results. The researchers observed also increasing liquidity of concrete mixtures and decreasing sorptivity of hardener concrete under the influence of latex based polymer. The knowledge of basic properties of microspheres from co-combustion of coal is fundamental to its effect usage of building industry.
\end{abstract}

Keywords: concrete, compressive strength tests, fly ash microsphere, latex base polymer.

\section{Introduction}

Concrete is the basic material used in construction industry which must satisfy appropriate mechanical properties describe in PN-EN $206+$ A1:2016-12 (Polski Komitet Normalizacyjny, 2003). Durability of concrete means maintaining mechanical properties in a definite time and in a specific environmental conditions. The introduction of new building technology and a growing demands of building materials with better and better technical properties enforce necessity of modifying the properties of concrete mixtures. The modification of properties of concrete mixtures is possible by using admixtures and additives. Effective usage of admixtures and additives is not an easy task. Many kinds of admixtures and additives are available on the market. The highest efficiency of admixtures and additives is only possible to achieve when the expected effect is comprehensively considered and analyzed at the stages: proportion of components, material characteristic of those components and on the conditions and method of conducting the technological processes during construction. The effect should be considered in both technical and ecological aspects. These aspects should be analyzed in relation to the designing, building and service life of constructions (Vičan, Śpiewak, Odrobinak, \& Ulewicz, 2017; Tsapko, 2018).

Admixtures of concrete are components, which are added during making concrete mixtures in the amount not exceeding $5 \%$ in relation to the cement mass. Admixtures could modify properties of both, concrete mixtures and hardened concrete. Plasticizing admixture was used in research described in the article. The result of adding the admixtures is increasing the mixture liquid (Yaphary, Lam, \& Lau, 2017; Dondelewski, 2008).

Additives of concrete are fine-grained, inorganic ingredients of concrete used to increase some properties or to obtain special properties of concrete. They are usually added to the concrete in amount above $5 \%$ in relation to the cement mass. Additives could significantly modify properties of both, concrete mixtures and hardened concrete. To prepare the specimens described in the article authors used microspheres and latex based polymer. Microspheres are fraction of emerging ashes as a result of burning of hard coal. Level of fineness is much smaller than ordinary fly ash (Yaphary et al., 2017; Dondelewski, 2008).

Striving for minimizing the negative impact of furnace wastes on the environment is the main in scientific consideration. Coal by-products produced in the energy sector are widely used in many areas, for example: construction 
industry, agricultural industry, mining industry. The coal by-products, mainly fly ash, are widely used in the building material industry (Kosior-Kazberuk, 2013; Hefni, Zaher, \& Wahab, 2018; Jones, McCarthy, \& Booth, 2006). According to research, the main chemical components of the microspheres in the oxide form is silicon, aluminium and iron, which comprise about $89 \%$ of their mass. They mineral ingredients are manly quartz and mullite $(\mathrm{Chen}, \mathrm{Ng}, \mathrm{Li}$, \& Kwan, 2017; Ebrahimi, Daiezadeh, Zakertabrizi, Zahmatkesh, \& Korayem, 2018; Wajda \& Kozioł, 2015).

Many studies have shown that ordinary fly ash tends to decrease early strength of concrete and increase significantly from 28 to 90 days. Many researchers reported, that compressive strengths of microspheres - modified concrete was very close to plain cement concrete and increased significantly from 28 to 90 days. It has been determined that concrete containing ultrafine fly ash can achieved higher long - term durability because of smaller size of fraction (Q. Wang, D. Wang, \& Chen, 2017; Chindaprasirt, 2005; Haque \& Kayali, 1998; Shaikh \& Supit, 2005; Hefni et al., 2018). Researchers were made also investigation on cement concrete containing latex addition. Many research have shown that, in terms of compressive strengths of concrete containing latex base polymer showed better performance than ordinary concrete (Moodi, Kashi, Ramezanianpour, \& Pourebrahimi, 2018; Ohama, 1987). In the science literature is not many research, in which this both components was combined. The aim of the research presented in this article is to determine the effect of adding microspheres and latex based polymer on the selected properties of concrete such as: compressive strength after 28 days since concreting, compressive strength after 90 days since concreting, freeze/thaw resistance test, compressive strength on the specimens after freeze/thaw resistance test, sorptivity and water absorption.

\section{Materials}

The test were carried on for concrete with Portland cement (CEM I $42.5 \mathrm{R}$ ), gravel fraction 2-16 mm, water from the municipal water supply network, $0-2 \mathrm{~mm}$ sand, latex based polymer, microspheres and HRWR.

To test the influence of microspheres and latex base polymer on mechanical and durability properties of concrete, nine different mix proportion of mentioned above components were prepared (in article mark as $\mathrm{C} 1$ to C9). The first series, marked as $\mathrm{C} 1$, is a reference for comparison of mechanical and durability properties of concrete. The series $\mathrm{C} 1$ was prepared without adding microspheres and latex based polymer. In the other eight series, one or both tested additives in different proportion were used. Concrete compositions are presented in Table 1.

Table 1. The amount of ingredients on $1 \mathrm{~m}^{3}$ concrete

\begin{tabular}{|c|c|c|c|c|c|c|c|}
\hline & $\begin{array}{c}\text { Cement } \\
(\mathrm{kg})\end{array}$ & $\begin{array}{c}\text { Water } \\
(\mathrm{kg})\end{array}$ & $\begin{array}{c}\text { Sand 0-2 mm } \\
(\mathrm{kg})\end{array}$ & $\begin{array}{c}\text { Gravel 2-16 mm } \\
(\mathrm{kg})\end{array}$ & $\begin{array}{c}\text { Latex based } \\
\text { polymer (kg) }\end{array}$ & $\begin{array}{c}\text { Microspheres } \\
(\mathrm{kg})\end{array}$ & $\begin{array}{c}\text { HRWR } \\
(\mathrm{kg})\end{array}$ \\
\hline $\mathrm{C} 1$ & 300 & 150 & 356 & 1633 & - & - & 3 \\
\hline $\mathrm{C} 2$ & 300 & 136.5 & 352 & 1614 & 22.5 & - & 3 \\
\hline $\mathrm{C} 3$ & 300 & 123 & 348 & 1595 & 45 & - & 3 \\
\hline $\mathrm{C} 4$ & 300 & 150 & 337 & 1544 & - & 30 & 3 \\
\hline $\mathrm{C} 5$ & 300 & 150 & 318 & 1456 & - & 60 & 3 \\
\hline C6 & 300 & 136.5 & 333 & 1526 & 22.5 & 30 & 3 \\
\hline C7 & 300 & 123 & 314 & 1438 & 22.5 & 60 & 3 \\
\hline C8 & 300 & 123 & 329 & 1507 & 45 & 30 & 3 \\
\hline C9 & 300 & 150 & 310 & 1419 & 45 & 60 & 3 \\
\hline
\end{tabular}

\section{Preparation of specimens}

The specimens were made and cured in line with PN-EN 12390-2 (PN-EN 12390-2 Making and curing specimens for strength test, in Polish Stand., 2001). To prepare tested concrete, all components from Table 1 were weighed and mixed in a concrete mixer. Then, the concrete was put in the cube forms of a $10 \times 10 \times 10 \mathrm{~cm}$. Specimens were thickened in two layers. The day after concreting, specimens were took out of cubes and put in water for 28 days. After 28 days, the article authors started a strength tests.

\section{Methods}

\section{Consistency test}

A consistency test was carried out as a flow table test according to PN-EN 12350-5 (PN-EN 12350-5 Testing fresh concrete. Part 5: Flow table test, in Polish Stand., 2011). The vertical and horizontal diameters were measured after removing a conical mould. The result was given as an average value. 


\section{Compressive strenght test after 28 days, after 90 days and after freeze/thaw resistance test}

A compressive strength test after 28 days, after 90 days and after freeze/thaw resistance were determined by using a testing machine ToniTechnik ToniPACT II. The rate of loading was maintained at $0.5 \mathrm{MPa} / \mathrm{s}$. Five specimens from each series were used to take the test. The half of them was tested after 28 days since concreting and the other half after 90 days. The test was conducted on $10 \times 10 \times 10 \mathrm{~cm}$ concrete cubes and expressed by the formula (1):

$$
F_{c}=\frac{10 \cdot F}{A_{c}},
$$

where: $F_{\mathrm{c}}-$ compressive strength of specimens $[\mathrm{MPa}] ; F-$ maximum load $[\mathrm{kN}] ; A_{c}-$ cross-sectional area of specimens $\left[\mathrm{cm}^{2}\right]$.

\section{Tensile splitting strength test}

A tensile splitting test was made in line with PN-EN 12390-6 (PN-EN 12390-6 Testing hardened concrete Part 6: Tensile splitting strength of test specimens, In Polish Stand., 2011). A tensile splitting strength test was determined using a testing machine ToniTechnik ToniPACT II. The rate of loading was maintained at 0,05 $\mathrm{MPa} / \mathrm{s}$. Five specimens from each series were used to take the test. The test was conducted on $10 \times 10 \times 10 \mathrm{~cm}$ concrete cubes and expressed by the formula (2):

$$
F_{c}=\frac{2 \cdot F}{\pi \cdot L \cdot d}
$$

where: $F_{c}-$ tensile splitting strength test $[\mathrm{MPa}] ; F-$ maximum load $[\mathrm{N}] ; L, d$ - the dimension of the cross - section $[\mathrm{mm}]$.

\section{Sorptivity test and water abrorption test}

A sorptivity test was conducted on halves of a cube specimens with an edge of $10 \mathrm{~cm}$ obtained from the tensile strength test. The specimens were placed in the distilled water at about $3 \mathrm{~mm}$ depth. The test consisted of weighing the samples after 15 minutes, 30 minutes and 1 hours since the immersing in the destilled water. The test lasted six hours. Sorptivity was defined as a slope of the linear function expressing the dependence of the mass of absorbed water on the time (3):

$$
\frac{\Delta m}{A_{S}}=S \cdot t^{0.5},
$$

where: $\Delta m$ - mass of absorbed water $[\mathrm{g}] ; A_{s}-$ area of the water ingress $\left[\mathrm{cm}^{2}\right] ; S$ - sorptivity $\left[\mathrm{g} /\left(\mathrm{cm}^{2} \cdot \mathrm{h}^{0.5}\right)\right] ; t-$ time $[\mathrm{h}]$.

A water absorption test was taken in line with PN-88/B-06250 (PN-EN 88/B-06250 'Plain concrete', in Polish Stand., 1988) on halves of $10 \mathrm{~cm}$-edged cubic specimens. The test was taken after 28 days of curing specimens in water. The water absorption were determined as (3):

$$
N_{w}=\frac{\left(G_{2}-G_{1}\right)}{G_{1}} \cdot 100 \%,
$$

where: $N_{w}$ - water absorption [\%]; $G_{1}$ - average mass of dry specimens [g]; $G_{2}$ - average mass of wet specimens [g].

\section{Freeze/thaw resistance test}

In each series, five similar specimens were used to make a freeze/thaw resistance test. The test consists of frosting specimens for 4 hours at the temperature $-18{ }^{\circ} \mathrm{C}$ then, defrosting at the temperature $+18{ }^{\circ} \mathrm{C}$ for 2 hours. The research consists of 150 freeze/thaw cycles. The evaluation of freeze/thaw resistance was based on:

- Visual checking condition of the specimens (the advent of cracks, destructions).

- Total mass of concert defects had not exceed $5 \%$ of the mass of specimens before the test.

- The result of compressive strength taken on specimens after the freeze/thaw resistance test cannot differ from the compressive strength test taken on specimens after 28 days more than $20 \%$. An average loss of compressive strength were determined as (4):

$$
\Delta R=\frac{\left(R_{1}-R_{2}\right)}{R_{1}} \cdot 100 \%,
$$

where: $\Delta R$ - loss of average compressive strength [MPa]; $R_{1}$ - average compressive strength after 28 days [MPa]; $R_{2}$ - average compressive strength of specimens subjected to freeze/thaw cycles [MPa]. 


\section{Results and discussion}

Results of consistency test

The results are presented in Table 2.

Table 2. The results of consistency test

\begin{tabular}{|l|c|c|c|c|}
\hline & Vertical dimeter $(\mathrm{mm})$ & Horizontal dimeter $(\mathrm{mm})$ & On average $(\mathrm{mm})$ & Concrete class \\
\hline C1 & 380.0 & 435.0 & 407.5 & F2 \\
\hline C2 & 485.0 & 465.0 & 475.0 & F3 \\
\hline C3 & 540.0 & 520.0 & 530.0 & F4 \\
\hline C4 & 375.0 & 510.0 & 443.0 & F3 \\
\hline C5 & 350.0 & 360.0 & 355.0 & F3 \\
\hline C6 & 470.0 & 420.0 & 445.0 & F2 \\
\hline C7 & 400.0 & 410.0 & 405.0 & F5 \\
\hline C8 & 565.0 & 550.0 & 557.5 & F3 \\
\hline C9 & 460.0 & 460.0 & 460.0 & \\
\hline
\end{tabular}

The consistency is a measure of the liquidity of concrete mixture. The highest liquidity was characteristic for specimens from series C8. Latex base polymer in amount $15 \%$ in relation to cement mass and microspheres in amount $10 \%$ in relation to cement mass were used to prepare specimens from series $\mathrm{C} 8$. The lowest results were achieved by specimens from series C5, which were prepared with microspheres in amount $20 \%$ in relation to cement mass. Concrete consistency class was determined in line with PN-EN 12350-5:2011 (PN-EN 12350-5 Testing fresh concrete. Part 5: Flow table test, in Polish Stand., 2011).

Results of compressive strength test after 28 days, after 90 days and on specimens after freeze/thaw resistance test

Table 3 presents results of the compressive strength test after 28 days, after 90 days since concreting, and on specimens after the freeze/thaw resistance test. The results given in the table are the average value of five specimens from each series.

Table 3. The results of compressive strength tests

\begin{tabular}{|l|c|c|c|}
\hline & $\begin{array}{c}\text { Average compressive strength } \\
\text { test after 28 days (MPa) }\end{array}$ & $\begin{array}{c}\text { Average compressive strength } \\
\text { test after 90 days (MPa) }\end{array}$ & $\begin{array}{c}\text { Average compressive strength test on speci- } \\
\text { mens after freeze/thaw resistance test (MPa) }\end{array}$ \\
\hline C1 & 53.51 & 60.45 & 49.24 \\
\hline C2 & 47.42 & 51.51 & 41.75 \\
\hline C3 & 44.53 & 49.33 & 18.85 \\
\hline C4 & 52.93 & 57.82 & 24.49 \\
\hline C5 & 47.96 & 53.46 & 25.15 \\
\hline C6 & 43.72 & 50.23 & 37.36 \\
\hline C7 & 40.87 & 44.64 & 39.36 \\
\hline C8 & 40.56 & 44.27 & 32.22 \\
\hline C9 & 43.66 & 49.16 & 34.99 \\
\hline
\end{tabular}

The highest average compressive strength after 28 days was achieved by specimens from series $\mathrm{C} 1$ 53.51 MPa. The second highest result was achieved by series C4 - 52.93 MPa. Specimens C1 were prepared without additives. Specimens C4 were prepared with microspheres in amount $10 \%$ in relation to cement mass. The lowest average compressive strength test after 28 days was achieved by specimens from series $\mathrm{C} 8-40.56 \mathrm{MPa}$ and $\mathrm{C} 7-$ $40.87 \mathrm{MPa}$. Both microspheres and latex based polymer were used to prepare specimens from series C8 and C7. Microspheres in amount $10 \%$ in relation to cement mass were used along with latex base polymer in amount $15 \%$ in relation to cement mass in series C8. Microspheres in amount $20 \%$ in relation to cement mass and latex base polymer in amount $7.5 \%$ in relation to cement mass were added together in series $\mathrm{C} 7$.

The highest average compressive strength after 90 day since concreting was achieved also by specimens without admixtures - 60.45 MPa. The average compressive strength after 90 days was achieved by specimens $\mathrm{C} 1$, 
accordingly $4.35 \%$ and $11.56 \%$ higher than the average compressive strength for series $\mathrm{C} 4$ and $\mathrm{C} 5$. The lowest results were observed also for specimens from series C8.

The highest result of compressive strength test on specimens after the freeze/thaw resistance test was achieved for specimens from series $\mathrm{C} 1$. The second highest result was achieved by specimens from series $\mathrm{C} 2$. Specimens form series C3 were marked with the lowest average compressive strength. Latex based polymer in amount $15 \%$ in relation to cement mass was used to prepare specimens from series $\mathrm{C} 3$.

Scientific research have shown, that concrete containing finer fly ash or latex base polymer achieved better performance than ordinary concrete (Wang et al., 2017; Moodi et al., 2018). The research made by authors clearly shown that, connection this two additions get worse the compressive strengths of specimens in each age. Non - modified concrete achieved the highest results. Especially surprising is fall in compressive strength of concrete containing fly ash microspheres.

\section{Result of tensile splitting strength test}

Table 4 presents results of tensile splitting strength test. The results given in the table are average of five specimens from each series.

Table 4. Results of tensile splitting strength test

\begin{tabular}{|l|c|}
\hline & Average tensile splitting strength test (MPa) \\
\hline C1 & 3.79 \\
\hline C2 & 3.54 \\
\hline C3 & 3.30 \\
\hline C4 & 3.75 \\
\hline C5 & 3.51 \\
\hline C6 & 3.42 \\
\hline C7 & 3.42 \\
\hline C8 & 3.32 \\
\hline C9 & 3.47 \\
\hline
\end{tabular}

The highest tensile splitting strength was characteristic for specimens form series C1 (3.79 MPa) which were prepared without additives. Similar result was achieved by specimens from series C4 - 3.75 MPa. The lowest result was achieved by specimens from series $\mathrm{C} 3-3.30 \mathrm{MPa}$. Latex based polymer in amount $15 \%$ relation to cement mass was used to prepared specimens from series $\mathrm{C} 3$.

Results of sorptivity and water absorption test

Table 5 presents results of sorptivity and water absorption test.

Table 5. Results of sorptivity and water absorption test

\begin{tabular}{|c|c|c|c|c|}
\hline \multirow{2}{*}{ Series } & \multirow{2}{*}{$\begin{array}{c}\text { Sorptivity } \\
{\left[\mathrm{g} /\left(\mathrm{cm}^{2} \cdot \mathrm{h}^{0.5}\right)\right]}\end{array}$} & $\begin{array}{c}\text { Wverage mass of dried } \\
\text { specimens }(\mathrm{g})\end{array}$ & $\begin{array}{c}\text { Average mass of soaked } \\
\text { specimens }(\mathrm{g})\end{array}$ & Water absorption $(\%)$ \\
\cline { 3 - 5 } & 0.0994 & 1075.65 & 1124.12 & 4.51 \\
\hline $\mathrm{C} 1$ & 0.0801 & 1090.77 & 1143.35 & 4.82 \\
\hline $\mathrm{C} 2$ & 0.0645 & 1084.80 & 1139.00 & 5.00 \\
\hline $\mathrm{C} 3$ & 0.0898 & 1118.45 & 1169.60 & 4.67 \\
\hline $\mathrm{C} 4$ & 0.0866 & 1088.45 & 1142.78 & 5.00 \\
\hline $\mathrm{C} 5$ & 0.0702 & 1088.38 & 1135.25 & 4.79 \\
\hline C6 & 0.0558 & 1046.83 & 1098.75 & 4.96 \\
\hline C7 & 0.0490 & 1059.87 & 1110.38 & 4.77 \\
\hline C8 & 0.0429 & 1072.53 & 1124.47 & 4.85 \\
\hline C9 & & & \\
\hline
\end{tabular}

The highest sorptivity, which was $0.994 \mathrm{~g} /\left(\mathrm{cm}^{2} \cdot \mathrm{h}^{0.5}\right)$ was obtained for specimens from series $\mathrm{C} 1$, which were prepared without additives. The lowest sorptivity, which was $0.0429 \mathrm{~g} /\left(\mathrm{cm}^{2} \cdot \mathrm{h}^{0.5}\right)$, obtained for series C9. Both latex 
base polymer and microspheres was used to prepare specimens from series C9. Sorptivity of C9 was $57 \%$ lower than ordinary concrete $-\mathrm{C} 1$.

The highest water absorption were characteristic the specimens from series $\mathrm{C} 3-5 \%$ and $\mathrm{C} 5-5 \%$. Latex base polymer in amount $15 \%$ of cement mass was used to prepare specimens from series $\mathrm{C} 3$. Microspheres in amount $30 \%$ of cement mass was used to prepare specimens from series $\mathrm{C} 5$. The lowest water absorption was achieved by specimens from series $\mathrm{C} 1-4.51 \%$.

\section{Results of freeze/thaw resistance test}

In the Table 6, relative decrease of compressive strength results after 150 freeze/thaw cycles were presented. The loss of compressive strength on specimens after the freeze/thaw resistance test should not be higher than $20 \%$ in relation to the compressive strength test after 28 days. The loss of compressive strength of specimens after the freeze/thaw resistance test was not higher than $20 \%$ for five series: C1, C2, C6, C7 and C9. Figure 1 presents specimens before and after freeze/thaw resistance test. The specimens did not show any defects.

Table 6. Results of freeze/thaw resistance test - relative decrease of compressive strength

\begin{tabular}{|c|c|c|c|}
\hline & $\begin{array}{c}\text { Average compressive strength } \\
\text { test after 28 days } \\
\text { (MPa) }\end{array}$ & $\begin{array}{c}\text { Average compressive strength test on } \\
\text { specimens after freeze/thaw resistance } \\
\text { (MPa) }\end{array}$ & $\begin{array}{c}\text { Decrease of compressive } \\
\text { strength (related to the day 28) } \\
\text { (\%) }\end{array}$ \\
\hline C1 & 53.51 & 49.24 & 7.98 \\
\hline C2 & 47.42 & 41.75 & 1.96 \\
\hline C3 & 44.53 & 18.85 & 5.73 \\
\hline C4 & 52.93 & 24.49 & 53.73 \\
\hline C5 & 47.96 & 25.15 & 47.56 \\
\hline C6 & 43.72 & 37.36 & 14.55 \\
\hline C7 & 40.87 & 39.36 & 3.69 \\
\hline C8 & 40.56 & 32.22 & 20.56 \\
\hline C9 & 43.66 & 34.99 & 19.86 \\
\hline
\end{tabular}
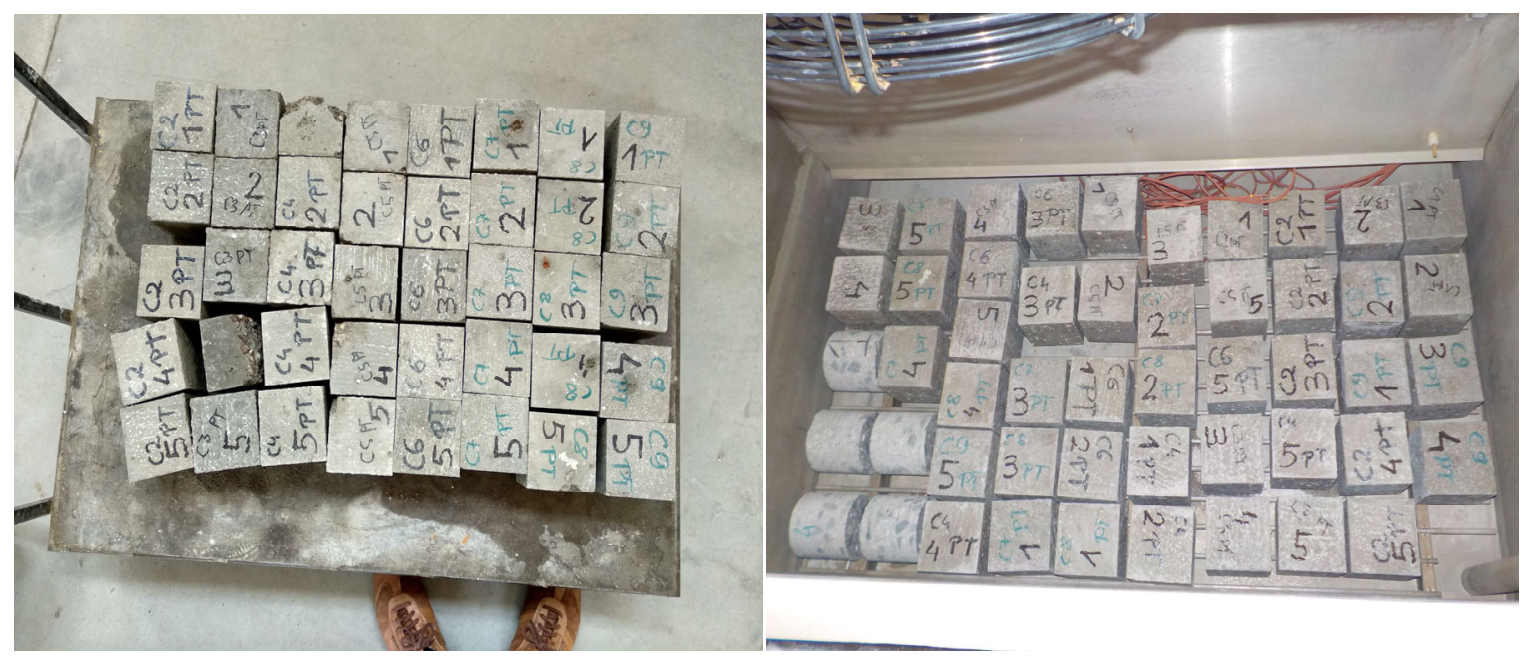

Figure 1. Specimens before and after 150 freeze/thaw cycles

\section{Conclusions}

Authors of the article carry out scientific research because of necessity of modification concrete mixtures and hardened concrete. The aim of scientific research is to design quantitative composition of concrete mixtures to improve the mechanical properties of hardened concrete. In this article there are research of selected properties of concrete made by using additives: microspheres and latex based polymer. The authors performed compressive strength test after 28 days, 90 days since concreting and on specimens after freeze/thaw resistance test. Base on the obtained test results the following conclusions could be formulated: 
- The tested additives used in proposed quantity on the weight of the cement decrease compressive strength of all of modified series of concrete. Latex base polymer has significantly decreased compressive strength test performed on specimens after freeze/thaw resistance test. The lowest medium result was achieved by the specimens was $18.85 \mathrm{MPa}$ and it was $57.67 \%$ less than specimens without additives. The highest medium result was achieved by specimens without additives in all three compressive strength tests and it amounted to $53.51 \mathrm{MPa}$.

- The results of consistency test show, that additive of latex based polymer contributed to increasing liquidity of concrete mixtures. The highest liquidity was characteristic for specimens from series $\mathrm{C} 8$, which was prepared with latex based polymer in amount $15 \%$ in relation to cement mass.

- The results show that using latex based polymer reduce concrete sorptivity and porosity and make concrete more watertight. Specimens with additive of latex based polymer (series C8 and C9) were characteristic the lowest sorptivity. The sorptivity achived by series C 8 and C9 was about $49 \%$ less than specimens from series $\mathrm{C} 1$.

The knowledge of basic properties of microspheres from co-combustion of coal is fundamental to its effect usage of building industry.

\section{References}

Chen, J. J., Ng, P. L., Li, L. G., \& Kwan, A. K. H. (2017). Production of high-performance concrete by addition of fly ash microsphere and condensed silica fume. Procedia Engineering, 172, 165-171. https://doi.org/10.1016/j.proeng.2017.02.045

Chindaprasirt, P., Jaturapitakkul, Ch., \& Sinsiri, Th. (2015). Effect of fly ash fineness on compressive strength and pore size of blended cement paste. Cement and Concrete Composites, 27(4), 425-428. https://doi.org/10.1016/j.cemconcomp.2004.07.003

Dondelewski, H. M. J. (2008). Betony cementowe. Warszawa: Wydawnictwo Naukowo Techniczne Sp. z o.o.

Ebrahimi, Kh., Daiezadeh, M. J., Zakertabrizi, M., Zahmatkesh, F., \& Korayem, A. H. (2018). (2018). A review of the impact of micro- and nanoparticles on freeze-thaw durability of hardened concrete: Mechanism perspective. Construction and Building Materials, 186, 1105-1113. https://doi.org/10.1016/j.conbuildmat.2018.08.029

Haque, M. N., \& Kayali, O. (1998). Properties of high-strenght concrete using a fine fly ash. Cement and Concrete Research, 28(10), 1445-1452. https://doi.org/10.1016/S0008-8846(98)00125-2

Hefni, Y., Zaher, Y. A. E., \& Wahab, M. A. (2018). Influence of activation of fly ash on the mechanical properties of concrete. Construction and Building Materials, 172, 728-734. https://doi.org/10.1016/j.conbuildmat.2018.04.021

Jones, M. R., McCarthy, A., \& Booth, A. P. P. G. (2006). Characteristics of the ultrafine component of fly ash. Fuel, 85(16), 2250-2259. https://doi.org/10.1016/j.fuel.2006.01.028

Kosior-Kazberuk, M. (2013). Surface scaling resistance of concrete with fly ash from co-combustion of coal and biomas. Procedia Engineering, 57, 605-613. https://doi.org/10.1016/j.proeng.2013.04.077

Moodi, F., Kashi, A., Ramezanianpour, A. A., \& Pourebrahimi, M. (2018). Investigation on mechanical and durability properties of polymer and latex-modified concretes. Construction and Building Materials, 191, 145-154. https://doi.org/10.1016/j.conbuildmat.2018.09.198

Ohama, Y. (1987). Principle of latex modification and some typical properties of latex -modified mortars and concretes. $A C I$ Materials Jurnal, 84(6), 511-518. https://doi.org/10.14359/2463

Polski Komitet Normalizacyjny. (1988). Plain concrete (PN-EN 88/B-06250).

Polski Komitet Normalizacyjny. (2003). Beton (PN-EN $206+$ A1:2016-12). Warszawa.

Polski Komitet Normalizacyjny. (2011). Making and curing specimens for strength test (PN-EN 12390-2).

Polski Komitet Normalizacyjny. (2011). Testing fresh concrete. Part 5: Flow table test (PN-EN 12350-5).

Polski Komitet Normalizacyjny. (2011). Testing hardened concrete - Part 6: Tensile splitting strength of test specimens (PN-EN 12390-6).

Shaikh, F. U. A., \& Supit, S. W. M. (2015). Compressive strength and durability properties of high volume fly ash (HVFA) concretes containing ultrafine fly ash (UFFA). Construction and Building Materials, 82, 192-205. https://doi.org/10.1016/j.conbuildmat.2015.02.068

Tsapko, K. (2018). The economic and technological efciency of building producton in view of contemporary industrial building materials. In MATEC Web of Conferences, 196, 04074. https://doi.org/10.1051/matecconf/201819604074

Vičan, J., Śpiewak, A., Odrobinak, J., \& Ulewicz, M. (2017). Effect of environmental actions on engineering constructions. In MATEC Web of Conferences, 117, 00175. https://doi.org/10.1051/matecconf/201711700175

Wajda, A., \& Kozioł, M. (2015). Mikrosfery - pozyskiwanie, właściwości, zastosowanie [Microspheres - acquisition, properties, applications]. Inżynieria Środowiska. Piece przemystowe \& kotly, 1, 15-17.

Wang, Q., Wang, D., \& Chen, H. (2017). The role of fly ash microsphere in the microstructure and macroscopic properties of high-strength concrete. Cement and Concrete Composites, 83, 125-137. https://doi.org/10.1016/j.cemconcomp.2017.07.021

Yaphary, Y. L., Lam, R. H. W., \& Lau, D. (2017). Chemical technologies for modern concrete production. Procedia Engineering, 172, 1270-1277. https://doi.org/10.1016/j.proeng.2017.02.150 